\title{
Self-stimulation in the rock squirrel as a function of current direction
}

JAMES E. KING, UNIVERSITY OF ARIZONA MARY C. WETZEL, SOUTHERN ARIZONA MENTAL HEALTH CENTER

Rock squirrels were trained to self-stimulate for monophasic stimulation of the lateral hypothalamus and subthalamus through bipolar electrodes. Current direction was systematically varied as were the intervals between successive measurements (10 $\mathrm{min}, 24 \mathrm{~h}$, or 7 days). Higher response rates were observed when the cathode was lateral to the anode than when the cathode was medial to the anode. The difference in response rates was independent of the intervals between measurements.

Most previous experimentation on self-stimulation of the brain has involved the use of biphasic current. An exception was a study by Wetzel \& King (1966) in which rats and rock squirrels self-stimulated for monophasic pulses delivered to the region of the lateral hypothalamus by bipolar electrodes. An interesting outcome of this study was a difference in response rates depending upon the polarity of the electrodes. The Ss evidenced higher response rates when the current flowed in one direction than when it flowed in the opposite direction, although the electrode separation was less than $.5 \mathrm{~mm}$. The experiment described here was designed to show whether or not this rate difference depended upon systematic positioning of the cathode and anode. A second purpose was to assess the dependence of polarity rate differences upon intervals between tests, when each test included measures for both cathode positions. These intervals were $10 \mathrm{~min}, 24 \mathrm{~h}$, and 7 days.

\section{Method}

The Ss were one male and 11 female rock squirrels (Citellus variegatus), all of which had been captured as adults. Bipolar electrodes were constructed from .01 in. diameter $90 \%$ platinum-10\% iridium wires which were cemented together and insulated except at the cross section of the tips. The electrodes were implanted in the right lateral hypothalamus and subthalamus (see Wetzel, King, \& Nowicki, 1967), and were placed such that the two electrode wires lay in one frontal plane. The Ss were tested in a Gerbrands operant chamber equipped with a response bar. Each bar press resulted in a $200 \mu \mathrm{A}$ monophasic train of $.5 \mathrm{msec}$ pulses delivered at a rate of 200 per sec. The duration of the pulse train was .2 sec for all Ss except one, S24, which was tested with a $.7 \mathrm{sec}$ train duration.

All Ss were initially trained to press the response bar during the course of not more than four daily training sessions. In the subsequent testing, the selfstimulation rate of each $S$ was measured when the cathode of the bipolar electrode was lateral to the anode (Condition L) and when the cathode was medial to the anode (Condition M). During a daily testing ses- sion, all Ss first received four 5-min self-stimulation periods with continuous reinforcement, each separated by a $2-$ min extinction period. This was followed by a 10-min extinction period and then four more selfstimulation periods again separated by 2-min extinction periods. At the beginning of each testing session and after each extinction period, $E$ induced $S$ to start responding by a shaping procedure in which $E$ delivered not more than 50 manual stimulations to $\mathrm{S}$. The pulse polarity over the eight self-stimulation periods in each session was varied according to the sequence LMMLMLLM for four Ss and MLLMLMML for the remaining elght Ss.

All Ss received four dally sessions as described above. Then, following an interval of seven days without testing, four more dally sessions were administered under the same procedures as before. Thus a measure of response rate under both the $L$ and the $M$ polarities was available with $10 \mathrm{~min}, 24 \mathrm{~h}$, or 7 day intervals between the measures.

Results

In Fig. 1 are shown the individual summaries of mean response rate per min during each of the eight

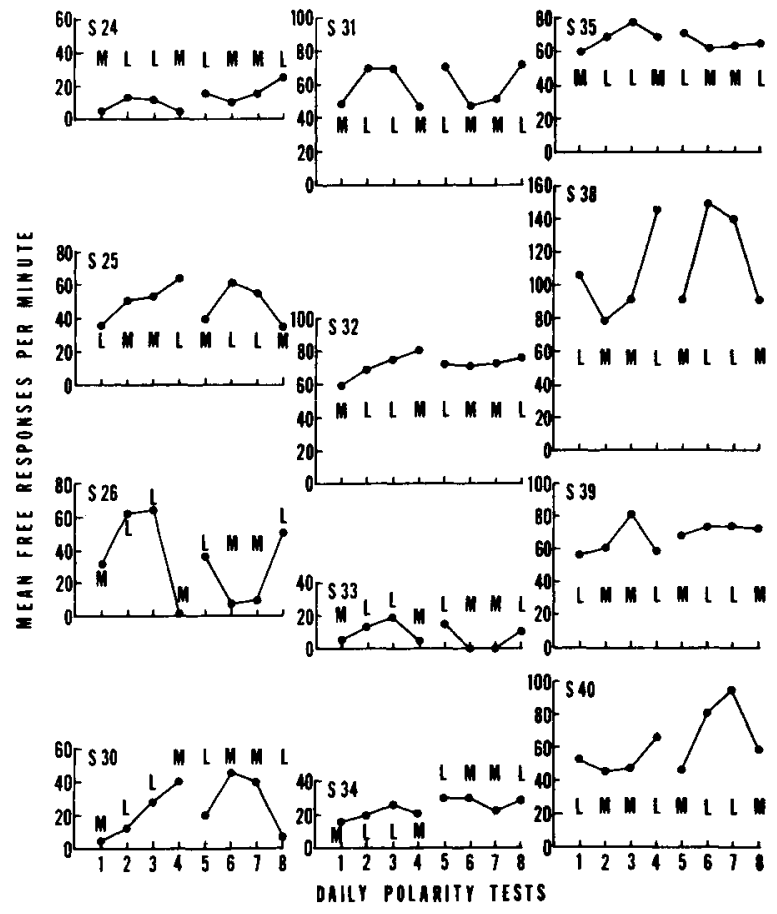

Fig. 1. Mean response rate per $\mathrm{min}$ averaged over the eight experimental days for individual $S$, during each of eight 5 -min $L$ and $M$ polarity tests. 
5-min self-stimulation periods presented in each testing session. Ss 24, 25, 26, 31, 33, 38, and 40 showed consistently higher rates under Condition $L$ than under Condition $M$. Overall mean rates under $L$ were also higher for Ss 34 and 35 , but the difference was less clear-cut within daily sessions. No rate difference between $L$ and $M$ was apparent for Ss 32 and 39. Only S30 consistently responded at a higher rate under the $M$ condition. Furthermore, an analysis of variance revealed significantly greater response rates under Condition $\mathrm{L}(\mathrm{F}=6.52, \mathrm{df}=1 / 11, \mathrm{p}<.05)$. The interactions of the polarity differences with each of the three temporal intervals (10 $\mathrm{min}, 24 \mathrm{~h}$, or 7 days) were all nonsignificant. Thus the higher response rates under Condition $L$ remained so throughout the course of testing.

There were significantly more responses during the second four days of testing than during the first four days ( $F=5.67$, df $=1 / 11, p<.05$ ). However, there was no significant change in response rate from day to day within the first and second four-day blocks, nor was there any significant change after the 10-min extinction period each test day.

Discussion

The central finding of this experiment was that rock squirrels evidenced higher response rates for selfstimulation of the hypothalamus and subthalamus when the cathode of a bipolar electrode was lateral to the anode than when the cathode was medial to the anode. This difference occurred despite a small interelectrode distance and despite a considerable variation in the implantation sites (see Wetzel, King, \& Nowicki, 1967, for brain sections). Because complex electrical and neural events occur under active electrode tips, reversing the polarity alters many variables. If one assumes, however, that the cathode is the most effective electrode for self-stimulation (cf., Valenstein \& Beer, 1961), then reversing the polarity alters stimulation locus slightly. If a gradient of stimulation effectlveness existed along the medial-lateral dimension, it would follow that one polarity should elicit higher response rates than the reverse polarity. The existence of such a gradient has been suggested by reports that stimulation of the lateral hypothalamus ylelds purely positive reinforcement, while stimulation of more medial sites usually yields mixed, positive and negative, effects (cf., Olds \& Olds, 1963; Poschel, 1966). Whether polarity effects are in fact dependent upon such a gradient is, however, speculative.

The difference in response rate attendant upon current polarity remained essentially constant following $10 \mathrm{~min}, 24 \mathrm{~h}$, or 7 day intervals during which the Ss received no ICS. This result is evidence that the response rate differences were not artifacts resulting from progressive tissue damage from the monophasic current. Wetzel \& King's (1966) finding of a cumulative response failure in rock squirrels was not replicated. Although only two Ss (31 and 32) self-stimulated during every period on every day, periods of nonresponding by the other Ss were irregular rather than cumulative.

Finally, the relative ease with which rock squirrels were trained to self-stimulate was in sharp contrast to the extreme difficulty we have experienced in training feral raised Ss of this species to make responses reinforced with food. This emphatically demonstrates the compelling nature of intracranial reinforcement (see Wolff, 1965).

\section{References}

OLDS, M. E., \& OLDS, J. Approach-avoidance analysis of rat diencephalon. J. comp. Neurol, 1963, 120, 259-295.

POSCHEL, B. P. H. Comparison of reinforcing effects yielded by lateral versus medial hypothalamic stimulation. J. comp. physiol. Psychol, $1966,61,346-352$.

VALENSTEIN, E. S., \& BEER, B. Unipolar and bipolar electrodes in self-stimulation experiments. Amer. J. Physiol, 1961, 201, 11811186

WOLFF, P. Brain stimulation and control of behavior. Psychol Rep., $1965,17,257-258$.

WETZEL, MARY C., \& KING, J. E. Self-stimulation with monophasic current in the rock squirrel and rat. Psychon. Sci, 1966, 6,7-8.

WETZEL, MARY C., KING, J. E., \& NOWICKI, L. E. Some monophasic self-stimulation loci in the rock squirrel and rat. Psychon. Sci, 1967, in press. 